\title{
A study to determine scar integrity in pregnant women with previous lower segment caesarean section
}

\author{
Divya Mangla ${ }^{1}$, Sunder Pal Singh ${ }^{1}$, Swasty $^{2}$, Jyoti Chauhan ${ }^{1}$
}

\author{
${ }^{1}$ Department of Obstetrics and Gynecology, S.H.K.M. Government Medical College Nalhar, Mewat, Haryana, India \\ ${ }^{2}$ Department of Obstetrics and Gynecology, Subharti Medical College Meerut, UP, India
}

Received: 03 January 2016

Revised: 13 February 2016

Accepted: 15 February 2016

\section{*Correspondence:}

Dr. Sunder Pal Singh,

E-mail: sunderdahiya@yahoo.co.in

Copyright: () the author(s), publisher and licensee Medip Academy. This is an open-access article distributed under the terms of the Creative Commons Attribution Non-Commercial License, which permits unrestricted non-commercial use, distribution, and reproduction in any medium, provided the original work is properly cited.

\begin{abstract}
Background: The purpose of this study was to assess the radiological characteristics of previous caesarean section scar and their correlation with clinico-pathological parameters, in order to decide mode of delivery.

Methods: This prospective longitudinal study was conducted on 200 women who had previous caesarean section and were at 36 weeks or more of gestation period and came in labor or taken for caesarean section from the antenatal clinic of Department of Obstetrics \& Gynecology, Subharti Medical College from the period January 2011 to December 2013.Radiological evaluation of previous caesarean section scar was done using transvaginal sonography (TVS) for all the women 54 women went through caesarean section and for them peroperatively mechanical measurement of scar thickness was done by ophthalmic calliper to correlate with the scar thickness in USG. Peroperatively scar tissue was taken for histopathological evaluation.

Results: 168 women with previous caesarean section underwent trial of labor and 114 women had vaginal delivery $(67.8 \%)$. As per this study there was a statistically significant correlation between scar thickness measured at or after 36 weeks of gestation and mode of delivery $(\mathrm{p}<.0001)$. Statistically significant correlation was also found between scar thickness measured prior to shifting for caesarean and peroperative scar thickness measurement by calliper. In histopathology, presence of fibro-collagenous tissue indicates weaker scar.

Conclusions: TVS should be used as an effective tool to measure the scar integrity, which will be helpful in deciding the mode of delivery. This will improve predictability of scar dehiscence or scar rupture in labor and hence choice of patients for successful VBAC may be made with greater accuracy. The pathological and biomechanical behavior evaluation of scar was done in this study in order to strengthen the radiological finding to decide the mode of delivery.
\end{abstract}

Keywords: TVS, VBAC, POG

\section{INTRODUCTION}

Caesarean section is the most common surgical intervention performed in modern obstetrics. There is a rise in caesarean section rate in past few years with every third of them being repeat caesarean section. Trial of labour after caesarean section (TOLAC) remains an attractive option for many patients and leads to a successful outcome in a high proportion of cases. Mode of delivery in cases of pregnant women with previous caesarean section was often questionable, since the risk of scar dehiscence continued to elude the obstetrician and the status of previous caesarean section scar remains an enigma. Despite the fact that scar rupture was a catastrophic complication of an attempt to VBAC delivery, vaginal births are preferred. The benefits of a VBAC include reduced risk of thrombo-embolism, 
shorter duration of hospital stay, lesser requirement of blood transfusion, lower rate of postpartum fever, wound infection, uterine infection and fewer neonatal problems. ${ }^{1}$

The present study was designed to determine whether the clinical, radio pathological and biomechanical criteria can be utilized to devise objective method for decision making regarding mode of delivery in patients with previous caesarean section without compromising maternal and fetal outcomes.

\section{METHODS}

Pregnant women with one previous caesarean section presenting in antenatal clinic at or after 36 weeks POG were recruited in the study from the period January 2011 to December 2013. Women who fulfilled the inclusion criteria were assessed by history and clinical examination. A thorough obstetric examination was done. Routine investigations were done. An informed consent was taken for inclusion in this study.

Scar thickness was assessed by TVS at or after 36 weeks of POG whichever was earlier, again in labour and before shifting the women for caesarean section. The lower uterine segment was measured in the sagittal plane. Measurements were taken at multiple sites of the lower uterine segment and its thinnest portion was considered to be the scar. A comprehensive scan of the lower uterine segment in various planes was done to look for any asymptomatic uterine dehiscence. Scar rupture was defined as complete disruption of myometrium along with the serosa and the fetal membranes whereas uterine dehiscence is defined as asymptomatic disruption of myometrium only. ${ }^{2}$ Women were shifted for CS if there was indication for the same.

The thickness of the lower uterine segment was measured at four different places by using ophthalmic caliper after giving the incision over the previous uterine scar and rupturing the membranes but before the delivery of the baby. The mean of these values was taken as peroperative scar thickness.

A biopsy specimen consisted a full thickness strip that was collected with metzenbaum scissors from the upper lip of the lower uterine segment incision immediately after the delivery of fetus and placenta. The sample was fixed immediately in $10 \%$ buffered formaldehyde for 4 hours and sent for histopathological examination. Maternal and fetal outcome was documented.

\section{RESULTS}

A total of 200 women with previous caesarean section were recruited at or after 36 weeks POG, of which 32 women were lost to follow up. The mean age of the study group was $26.79 \pm 3.10$ years. The interval between previous caesarean and current pregnancy was between 25 months to 36 months in maximum number of enrolled women. 168 women who stayed in the study had a TVS at 36 weeks POG for measurement of scar thickness (mean scar thickness - 3.49 $\pm 1.08 \mathrm{~mm}$ ) and had a repeat TVS at the time of labour (mean scar thickness $2.97 \pm 0.96 \mathrm{~mm}$ ). 114 women underwent vaginal delivery while 54 women were shifted for caesarean section. Scar thickness was measured again for these 54 women prior to shifting for caesarean section (mean scar thickness $2.460 \pm 0.96 \mathrm{~mm})$. Mean scar thickness when measured peroperatively by calliper was $2.35 \pm 0.78 \mathrm{~mm}$. Fetal distress and meconium stained liquor were the most common indications of repeat Caesarean section in women. One case of obstructed labour was presented for which per operative scar rupture was found and scar thickness when measured prior to shifting for CS was 1 $\mathrm{mm}$. Scar dehiscence detected per operatively was seen in 5 cases $(9.3 \%)$. Interval between previous caesarean and current pregnancy was significantly more in the vaginal delivery group with the $p$ value of $<0.001$. A statistically significant data was found $(p<0.0001)$ when TVS measured scar thickness was compared at or after 36 weeks of POG with labour (Table 1). TVS measured scar thickness prior to shifting for caesarean section was compared with peroperative measured scar thickness by calliper (Table 2). Study showed that the women with lesser scar thickness, dehiscence and rupture had more amount of fibro collagenous tissue on histopathology (Table 3). Maternal outcome in this study was noted in terms of mode of delivery as well as operative and postoperative complications (wound dehiscence, febrile morbidity \& blood transfusion). In our study fetal outcome in vaginal and caesarean deliveries were documented in terms of low birth weight $(9.6 \%$ vs. $5.6 \%)$, admission to NICU (1.8\% vs. $1.9 \%)$, Apgar score of less than 7 at 5 minutes (none vs 1.9\%), transient tachypnea of newborn, (none vs. $0.9 \%$ ), neonatal sepsis (none vs $1.9 \%$ ).

Table 1: Correlation of scar thickness measured by

TVS at or beyond 36 weeks of gestation with scar thickness measured in labour.

\begin{tabular}{|lll|}
\hline $\begin{array}{l}\text { Scar } \\
\text { thickness } \\
(\mathrm{mm})\end{array}$ & $\begin{array}{l}\text { Scar thickness } \\
\text { measured at or } \\
\text { beyond 36 weeks } \\
\text { of gestation by } \\
\text { TVS }(\mathrm{N}=168)\end{array}$ & $\begin{array}{l}\text { Scar thickness } \\
\text { measured in } \\
\text { labour by TVS } \\
(\mathrm{N}=168)\end{array}$ \\
\hline 1 & $5(2.90 \%)$ & $2(1.2 \%)$ \\
\hline $1-2$ & $20(11.9 \%)$ & $2(1.2 \%)$ \\
\hline $1-3$ & $50(29.8 \%)$ & $106(63.4 \%)$ \\
\hline $1-4$ & $68(40.4 \%)$ & $58(34.2 \%)$ \\
\hline $1-5$ & $20(11.9 \%)$ & - \\
\hline $1-6$ & $4(2.4 \%)$ & - \\
\hline $1-7$ & $1(0.7 \%)$ & - \\
\hline Mean \pm SD & $3.49 \pm 1.08$ & $2.97 \pm 0.96$ \\
\hline
\end{tabular}

$\mathrm{P}<0.0001$ 
Table 2: Correlation of scar thickness measured by TVS at or beyond 36 weeks of gestation vs mode of delivery.

\begin{tabular}{|ll|}
\hline $\begin{array}{l}\text { Sear thickness }(\mathrm{mm}) \text { by } \\
\text { TVS at or after } 36 \text { weeks }\end{array}$ & $\begin{array}{l}\text { Mode of delivery } \\
\text { Vaginal delivery }(\mathrm{n}=114)\end{array}$ \\
\hline $1-2$ & $0(0.0 \%)$ \\
\hline $1-3$ & $12(10.5 \%)$ \\
\hline $1-4$ & $52(45.6 \%)$ \\
\hline $1-5$ & $34(29.8 \%)$ \\
\hline $1-6$ & $15(13.2 \%)$ \\
\hline$>6$ & $1(0.9 \%)$ \\
\hline Mean \pm SD & $3.74 \pm 0.93$ \\
\hline
\end{tabular}

Table 3: Correlation of scar thickness measured by TVS in labour vs mode of delivery.

\begin{tabular}{|lll|}
\hline $\begin{array}{l}\text { Scar thickness in } \\
\text { mm measured in } \\
\text { labour }(\mathrm{mm})\end{array}$ & $\begin{array}{l}\text { Mode of delivery } \\
\text { Vaginal } \\
\text { delivery }(\mathrm{n}=114)\end{array}$ & $\begin{array}{l}\text { Caesarean } \\
\text { delivery }(\mathrm{n}=54)\end{array}$ \\
\hline 1 & $0(0.0 \%)$ & $2(3.7 \%)$ \\
\hline $1-2$ & $12(10.5 \%)$ & $2(3.7 \%)$ \\
\hline $1-3$ & $62(54.4 \%)$ & $36(66.6 \%)$ \\
\hline $1-4$ & $40(35.1 \%)$ & $14(26.0 \%)$ \\
\hline Mean \pm SD & $3.21 \pm 0.56$ & $2.46 \pm 0.96 \mathrm{~mm}$ \\
\hline
\end{tabular}

Table: 4 Correlation of scar thickness measured by TVS prior to shifting for caesarean and scar thickness measured peroperatively by caliper.

\begin{tabular}{|lll|}
\hline $\begin{array}{l}\text { Scar } \\
\text { thickness in } \\
\text { mm }\end{array}$ & $\begin{array}{l}\text { Prior to shifting } \\
\text { for caesarean } \\
\text { measured by TVS } \\
\text { in } \mathrm{mm} \\
(\mathrm{N}=54)(\%)\end{array}$ & $\begin{array}{l}\text { Peroperative } \\
\text { measurement of } \\
\text { scar thickness } \\
\text { by calliper in } \\
\text { mm }(\mathrm{N}=54)(\%)\end{array}$ \\
\hline $\begin{array}{l}\text { Scar rupture } \\
\text { Scar } \\
\text { dehiscence }\end{array}$ & 0 & $1(1.9)$ \\
\hline $1 \mathrm{~mm}$ & $2(4)$ & $5(9.3)$ \\
\hline $1.1-2 \mathrm{~mm}$ & $2(4)$ & $6(11.3)$ \\
\hline $2.1-3 \mathrm{~mm}$ & $36(66)$ & $22(40.8)$ \\
\hline $3.1-4 \mathrm{~mm}$ & $14(26)$ & $17(31.5)$ \\
\hline $\begin{array}{l}\text { Mean } \\
\text { deviation } \\
\pm \text { SD mm }\end{array}$ & $2.46 \pm 0.96 \mathrm{~mm}$ & $3(5.2)$ \\
\hline $\mathrm{P}<0.0001$ & $2.35 \pm 0.78 \mathrm{~mm}$ \\
\hline
\end{tabular}

\section{DISCUSSION}

The scar thickness measured sonographically at or after 36 weeks of gestation was $3.74 \pm 0.93 \mathrm{~mm}$ in those who delivered vaginally and $2.96 \pm 0.76 \mathrm{~mm}$ in those who delivered by caesarean. Thus the scar thickness at or beyond 36 weeks was lesser in patients who had caesarean delivery than those who delivered vaginally.
Table 5: Correlation of peroperative scar thickness and histopathological findings.

\begin{tabular}{|llcl|}
\hline $\begin{array}{l}\text { Peroperative } \\
\text { scar thickness } \\
\text { by calliper }\end{array}$ & $\begin{array}{l}\text { No of } \\
\text { cases } \\
\mathbf{N}=54\end{array}$ & $\begin{array}{l}\text { Fibro } \\
\text { collagenous } \\
\text { tissue } \mathbf{N}(\%)\end{array}$ & $\begin{array}{l}\text { Fibro } \\
\text { muscular } \\
\text { tissue N }(\%)\end{array}$ \\
\hline Scar rupture & 1 & $1(100)$ & 0 \\
\hline Scar dehiscence & 5 & $4(80)$ & $1(20)$ \\
\hline $1 \mathrm{~mm}$ & 6 & $4(66.6)$ & $2(33.4)$ \\
\hline $2 \mathrm{~mm}$ & 22 & $7(31.8)$ & $15(68.2)$ \\
\hline $3 \mathrm{~mm}$ & 17 & $5(29.4)$ & $12(70.6)$ \\
\hline $4 \mathrm{~mm}$ & 3 & 0 & $3(100)$ \\
\hline Mean \pm SD $2.35 \pm 078 \mathrm{~mm}$ & & \\
\hline
\end{tabular}

The scar thickness measured sonographically in labour was $3.21 \pm 0.56 \mathrm{~mm}$ in those who delivered vaginally and $2.46 \pm 0.96 \mathrm{~mm}$ in those who delivered by caesarean. Thus the scar thickness measured in labour was also lesser in patients who had caesarean delivery than those who delivered vaginally.

The above observation can be explained on the basis that LUS thins out during labour. Gotoh et al reported the scar thickness measured sonographically at 39 weeks as $3.0 \pm 0.7 \mathrm{~mm}$ in vaginal delivery group and $2.1 \pm 0.7 \mathrm{~mm}$ in those who had caesarean delivery. ${ }^{1}$ They also reported it to be significantly thinner in those having repeat caesarean.

In year 2004 Cheung, et al concluded that prior caesarean delivery are associated with a sonographically thinner LUS when compared with those with prior vaginal delivery. ${ }^{2}$ They also measured the scar thickness by TVS due to which delineation of the structures was clearer and bladder wall could be visualized separately from the myometrium. William michales, et al concluded that sonographic survillance is a reliable and practical means of evaluating the LUS after conception and before labour or delivery. ${ }^{3}$

In the present study there was a significant correlation of scar thickness measured at or after 36 weeks of gestation and in labour $(\mathrm{p}<0.0001)$ (Table 1). The progressive alteration could be documented.

Decrease in scar thickness was seen in $89.3 \%$ women. Scar thickness remained unchanged in $10.7 \%$ women. The success rate of VBAC in our study was $67.8 \%$. In a study conducted in Christian Medical College, Vellore, Tamil Nadu, India in 2004 by George, et al, The success rate of VBAC was $60 \% .{ }^{4}$ Western literature reports also have comparable rates of successful VBAC. According to the updated guidelines of ACOG regarding VBAC in 2010 the success rate of VBAC ranges between 60 to $80 \%$. Thus the rate of successful VBAC is reported in the lower range of spectrum in Indian literature and in the higher range of spectrum in Western Literature. This difference may be due to the lack of resources for emergency caesarean section in India, giving rise to 
increase number of elective caesarean section is such cases. Moreover due to better facilities of electronic fetal monitoring in the west the patients are allowed for trial of vaginal delivery till significant indication for caesarean section is there. Due to lack of such resources in India, it is possible that patients are taken up for caesarean section at the slightest indication leading to decrease in rate of successful VBAC. The success rate of VBAC in our study was found to be midway between the Indian and western data.

The rate of scar rupture in our study was $0.6 \%$ and that of asymptomatic uterine dehiscence diagnosed peroperatively was $2.9 \%$. The calliper measured scar thickness was correlated to the radio logically measured scar thickness prior to shifting for caesarean section (Table 2). Significant correlation was seen between per operative calliper measured scar thickness and radiologically measured scar thickness prior to shifting for LSCS $(\mathrm{p}<0.0001)$.

Prahlad Kuhtagi et al in their study on 106 women with previous caesarean delivery and 68 women with unscarred uterus concluded that pre labour USG can be useful in predicting thinning of previous caesarean scar in labour. ${ }^{5}$ The introduction of radiological evaluation of scar thickness into clinical practice for deciding mode of delivery in pregnancy with previous caesarean may contribute to increase success of trial of labour in such women.

One case was of rupture $\&$ this woman presented to us in obstructed labour. Rest 5 cases had scar dehiscence. TVS measured scar thickness in these 5 cases prior to shifting was in the range of 1-2 mm. Our study showed that the women with lesser scar thickness, dehiscence \& rupture had more amount of fibro collagenous tissue on histopathology (Table 3). It shows that quality of healing may affect the biochemical properties of scar tissue. We underline the necessity of further investigations to confirm our result and to examine their possible clinical and therapeutic implication. Fabrizio Pollio et al found in their study that in cases of uterine dehiscence scar tissue showed a higher collagen content. They hypothesized that uterine dehiscence of scarred uterus may be related to altered biochemical behaviour of the scarring process. ${ }^{6}$

No neonatal death was seen in any of the groups. No statistically significant difference was seen in neonatal outcome in both groups.

The inter-delivery interval i.e. the interval between previous caesarean and current pregnancy was 25 to 36 months in $33.3 \%$ of patients (maximum), $5.4 \%$ women had inter delivery interval of less than 12 months. Interval between previous caesarean and current pregnancy was found to be significantly more in the vaginal delivery group with $\mathrm{P}$ value of $<0.0001$.

\section{CONCLUSIONS}

TVS should be used as an effective tool to measure the scar integrity, which will be helpful in deciding the mode of delivery. This will improve predictability of scar dehiscence or scar rupture in labour and hence choice of patients for successful VBAC may be made with greater accuracy. The pathological and biomechanical behavior evaluation of scar was done in this study in order to strengthen the radiological finding to decide the mode of delivery.

\section{Funding: No funding sources Conflict of interest: None declared \\ Ethical approval: The study was approved by the Institutional Ethics Committee}

\section{REFERENCES}

1. Gotoh H, Masuzaki H, Yoshida A, Yoshimura S, Miyamura T, Ishirmaru T. Predicting incomplete uterine rupture with vaginal sonography during the late second trimester in women with prior Caesarean. Obstet Gynecol. 2000;95:596-600.

2. Cheung VYT, Constantinescu OC, Ahluwalia BS. Sonographic Evaluation of the Lower Uterine Segment in Patients with Previous Caesarean Delivery. Ultrasound Med. 2004;23:1441-7.

3. Michaels WH, Thompson HO, Bault A, Schreiber FR, Michaels SL, Karo J. Ultrasound diagnosis of defects in the scarred lower uterine segment during pregnancy. Ob stet Gynecol. 1988;71:112-20.

4. George A, Arasi KV, Mathai M. Is vaginal birth after caesarean delivery a safe option in India? International J Gynecol Obstet. 2004;85(1):42-3.

5. Kushtagi P, Garepalli S. Sonographic assessment of lower uterine segment at term in women with previous caesarean delivery. Arch Obset Gynecol. 283:455-9.

6. Sambaziotis H, Conway C, Figueroa R, Elimian A, Garry D. Comparison of the lower uterine segment in pregnant women with and without a previous Caesarean delivery. J Ultrasound Med 2004;23:90711.

Cite this article as: Mangla D, Singh SP, Swasty, Chauhan J. A study to determine scar integrity in pregnant women with previous lower segment caesarean section. Int J Reprod Contracept Obstet Gynecol 2016;5:711-4. 